\title{
Taxonomic Position and Seasonal Variations in Marine Neritic Environment of Some Gram-negative Antibiotic-producing Bacteria
}

\author{
By M. J. GAUTHIER \\ C.E.R.B.O.M., INSTITUT NATIONAL de la SANTÉ et de la RECHERCHE \\ MÉDICALE U 40, Nice 06300, France
}

J. M. SHEWAN AND D. M. GIBSON

Torry Research Station, Aberdeen AB9 $8 D G$

AND J. V. LEE

Public Health Laboratory, Preston Hall Hospital, Maidstone ME20 $7 \mathrm{NH}$, Kent

(Received I5 February 1974; revised 16 September 1974)

\section{SUMMARY}

Six marine bacteria which synthesize macromolecular antibiotics were isolated from neritic waters on the French Mediterranean coast, and their frequency recorded over two successive years.

They appeared in relatively large numbers during the period August to December, and can be identified as marine pseudomonads; however, the low guaninecytosine ratio of their DNA, lack of catalase and specific self-inhibition are not compatible with the characteristics of the genus Pseudomonas. Two produced violacein, usually synthesized by bacteria belonging to the genus Chromobacterium. Their taxonomic position is discussed.

\section{INTRODUCTION}

Many marine bacteria release antibacterial substances into culture media. These substances inhibit various terrestrial and in particular Gram-positive bacteria. Marine bacteria are widespread; they have been found in the Atlantic Ocean (Rosenfeld \& ZoBell, 1947; Grein \& Meyers, I958; Buck, Meyers \& Kamp, I962; Buck, Ahearn, Roth \& Meyers, 1963; Buck \& Meyers, 1965, 1966; Burkholder, Pfister \& Leitz, I966; Doggett, I968), the Indian Ocean (Baam, Gandhi \& Freitas, 1966; Lebedeva \& Markianovic, I97I), the Mediterranean Sea (Gauthier, I969; Lebedeva \& Markianovic, I97I), the Red Sea and the Gulf of Aden (Lebedeva \& Markianovic, I97I) and the Baltic Sea (Bonde, I968). They have been isolated from most marine biotopes, including surface or deep waters, immersed substrates, surface of seaweeds, and fine or rough sediments, and have been identified as species of Bacillus, Micrococcus, Pseudomonas, Vibrio, Flavobacterium, Alcaligenes, Xanthomonas and Achromobacter.

Bacteria isolated from reasonably unpolluted Mediterranean coastal waters near Nice are characterized by the macromolecular and polysaccharide nature of their antibacterial substance and by the mechanism of their inhibition of terrestrial bacteria, mainly Gram-positive species but also a few Gram-negative ones such as Klebsiella spp. and Escherichia spp. (Gauthier, 1970). Seasonal variations in the numbers of such bacteria within neritic heterotrophic bacterial populations over two successive years (1969-1970) are reported, together with their morphological, physiological and biochemical characters. 


\section{METHODS}

Bacteria. The six strains studied were Gram-negative heterotrophic rods, which periodically occurred in relatively large numbers in the water or at the surface of immersed substrates in the littoral area near Nice. The area is rocky and calcareous, and covered with an algal population of Cystoseira. Samples were taken at $10 \mathrm{~m}$ from the shore at a depth of $6 \mathrm{~m}$.

A single strain of each type studied was deposited in the C.E.R.B.O.M. collection (strains Nos. 6, I0, I8, 56, I I 4 and I23), later being acceded to the National Collection of Marine Bacteria (Torry Research Station, Aberdeen) as NCMB strains I943, I889, I890, I892, I942 and $194 \mathrm{I}$, respectively.

Media and enumeration. Bacterial counts were performed fortnightly for two years, using either filtration (Millipore filters, $0.45 \mu \mathrm{m}$ pore size) or direct spreading of samples on agar plates of ZoBell's medium $22 \mathrm{I} 6 \mathrm{E}$ (Bactopeptone $5 \mathrm{~g}$, yeast extract I g, $\mathrm{FePO}_{4} \mathrm{O}^{\circ} \mathrm{I} \mathrm{g}$, aged seawater $800 \mathrm{ml}$, distilled water $200 \mathrm{ml}, \mathrm{pH} \mathrm{7.6)}$. On this medium, they showed characteristic pigmentations which proved useful for rapid identification: NCMBI943, pinkish beige with reddish-brown diffusible pigment; NCMBI889, lemon yellow; NCMBI890, bright red, turning carmine in old cultures; NCMBI892, orange, soon becoming greenish-brown; NCMB I942, light violet; NCMBI94I, dark violet, almost black.

Their antibiotic activity against Staphylococcus aureus (Institut Pasteur, strain 209P) was tested by the double-layer technique used for studying bacteriocin production (Gratia \& Fredericq, I946). A small volume of each sample (0. I to I $\mathrm{ml}$ ) of an appropriate dilution was spread on the surface of the medium and incubated for 6 days at $20^{\circ} \mathrm{C}$. After being killed with chloroform (30 $\mathrm{min}$ ), the colonies were covered with a thin layer (I mm) of Trypticase soy agar sown with $S$. aureus (209P). After $18 \mathrm{~h}$ at $37^{\circ} \mathrm{C}$, the antibiotic-producing colonies showed a clear zone of inhibition. The violet colonies were counted separately. The counts of each of these pigmented types were then compared with the total number of heterotrophs in the sample.

Microscopy. Flagella were demonstrated by a modification of Rhodes' (1958) method. It was impossible to wash the bacteria before preparing the smears and especially before mordant action because of lysis, so rinsing was done very rapidly with $10 \%$ seawater, best results being obtained by doubling the concentration of the tannic acid solution.

Lysis also made it difficult to prepare specimens for electron microscopy. The bacteria, grown for $24 \mathrm{~h}$ on solid medium, were suspended in $5 \%(\mathrm{w} / \mathrm{v})$ formalin containing $3 \%$ $(\mathrm{w} / \mathrm{v}) \mathrm{NaCl}$. After rinsing 2 or 3 times in saline formalin and centrifuging $(2800 \mathrm{~g}, \mathrm{I} 5 \mathrm{~min}$, I0 $\left.{ }^{\circ} \mathrm{C}\right)$, the pellet was resuspended in $5 \%(\mathrm{w} / \mathrm{v})$ ammonium acetate, the bacteria shadowed with $\mathrm{Au} / \mathrm{Pd}$, and observed in a Siemens Elmiskop type I electron microscope.

General physiological and biochemical properties. The identification scheme for Gramnegative rods proposed by Shewan, Hobbs \& Hodgkiss (I960) and Hendrie, Hodgkiss \& Shewan (1964) was used. The violet pigments of strains NCMBI94I and NCMBI942 were extracted, purified and identified as described by Strong (I944).

Since the bacteria grew only on a medium of high ion content, sensitivity to $\mathrm{O} / \mathrm{I} 29$ was done on ZoBell's medium 22I6 E. Caution has to be exercised in interpreting negative results because this medium could inhibit the activity of O/I29 (Merkel, 1972).

Sodium requirements. These were studied with a biophotometer (Bonet-Maury, $425 \mathrm{~nm}$ ), in 'mock seawater' medium (Casitone $0.4 \%$, yeast extract $0.2 \%, \mathrm{NaCl}$ I $75 \%, \mathrm{KCl} 0 . \mathrm{I} \%$, $\mathrm{MgCl}_{2} .6 \mathrm{H}_{2} \mathrm{O} 0.4 \%, \mathrm{CaCl}_{2} .2 \mathrm{H}_{2} \mathrm{O} 0 . \mathrm{I} \%$; tris $0.05 \%$, distilled water $\mathrm{I} 00 \mathrm{ml}, \mathrm{pH} 7.6$ with $\mathrm{N}-\mathrm{HCl})$ in the presence of increasing concentrations of $\mathrm{NaCl}(0.00 \mathrm{I}, 0.05,0.1,0.2,0.4,0.6$, 0.8 and I M). Inoculation was carried out in biophotometer cells, with $0.05 \mathrm{ml}$ of a thick 


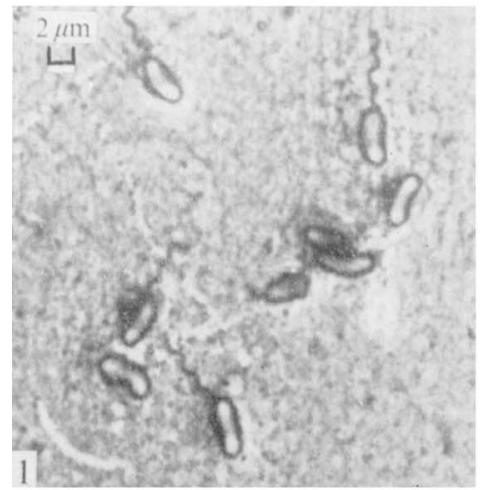

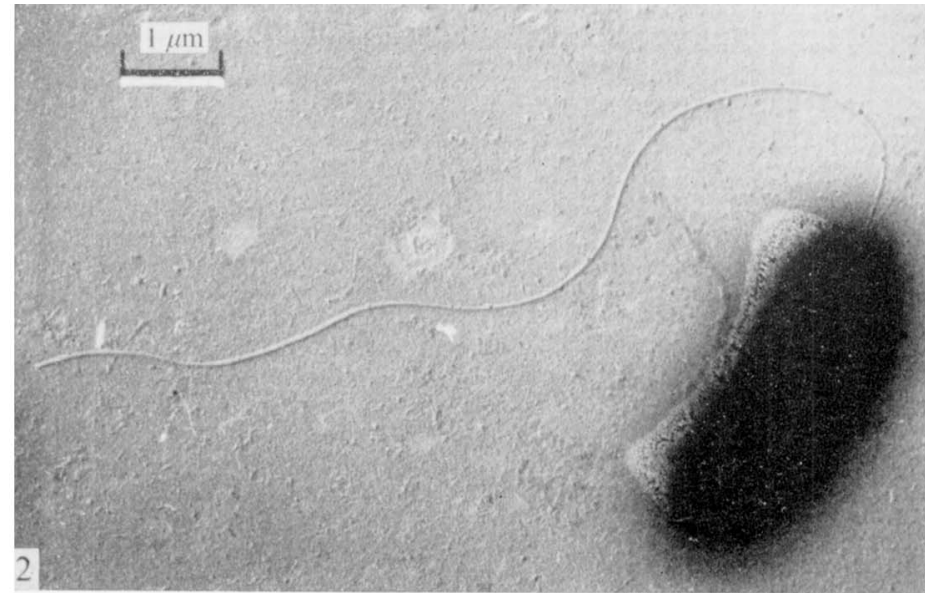

Fig. I. Flagella stain of strain NCMBI 890 , as described in text. This strain, like the five other types, is monotrichous and polar.

Fig. 2. Electron micrograph of strain NCMBI 890 showing typical pseudocapsule formation.

bacterial suspension in a medium containing $0 \cdot \mathrm{I} \mathrm{M}^{\mathrm{N}} \mathrm{Na}^{+}$. The duration of the lag phase and the maximum absorbance attained by each strain in each medium were measured.

Lytic phenomena. By using the technique of Chabbert (1963) the number of surviving bacteria was determined in a suspension of each strain in artificial saline solution $(\mathrm{KCl}$, $\mathrm{NaCl}, \mathrm{MgCl}_{2} \cdot 6 \mathrm{H}_{2} \mathrm{O}$ and $\mathrm{CaCl}_{2} \cdot 4 \mathrm{H}_{2} \mathrm{O}$ ), successively deprived of sodium, magnesium and calcium, or of all three elements simultaneously. The absorbance of each suspension was measured $\mathrm{I}$ min, $\mathrm{I} h$ and $\mathrm{I} 8 \mathrm{~h}$ after mixing, seawater, distilled water and sucrose (I $\mathrm{M}$ ) being used as references.

Base composition of DNA. The guanine-cytosine (GC) ratio of the DNA was determined by thermal denaturation (Marmur \& Doty, 1962) after extraction and purification of the DNA by the technique of Marmur (196I). It was not possible to purify DNA from strain NCMBI 892.

Quantitative variations during the year. The numbers of each of the six bacterial types in the water were obtained by the standard method of plating and counting, which underestimates the true count in the sample. However, since the total heterotrophic count was obtained in the same way, the proportion of antibiotic-producing strains in the whole population is probably accurate.

\section{RESULTS}

Taxonomic features

All microscopic observations (Figs. I and 2) showed the bacteria to be straight Gramnegative rods, of between $\mathrm{I} \cdot 5 \times \mathrm{I} \cdot 4$ and $4 \times \mathrm{I} \cdot 4 \mu \mathrm{m}$, motile by means of a single polar flagellum. The electron-dense pericellular zone suggested the presence of a loose pseudocapsule, but this could have been an artefact.

All were oxidase- and cytochrome oxidase-positive, but catalase-negative, insensitive to the vibriostat $\mathrm{O} / \mathrm{I} 29$ and to penicillin, and unable to ferment glucose in Leifson's (1963) medium. None produced fluorescent pigment in King's (1954) media A and B, or showed any growth at temperatures higher than $30^{\circ} \mathrm{C}$ (except for strain NCMBI 890). All were strongly proteolytic and readily hydrolysed starch, but were unable to reduce nitrates. The pigment 


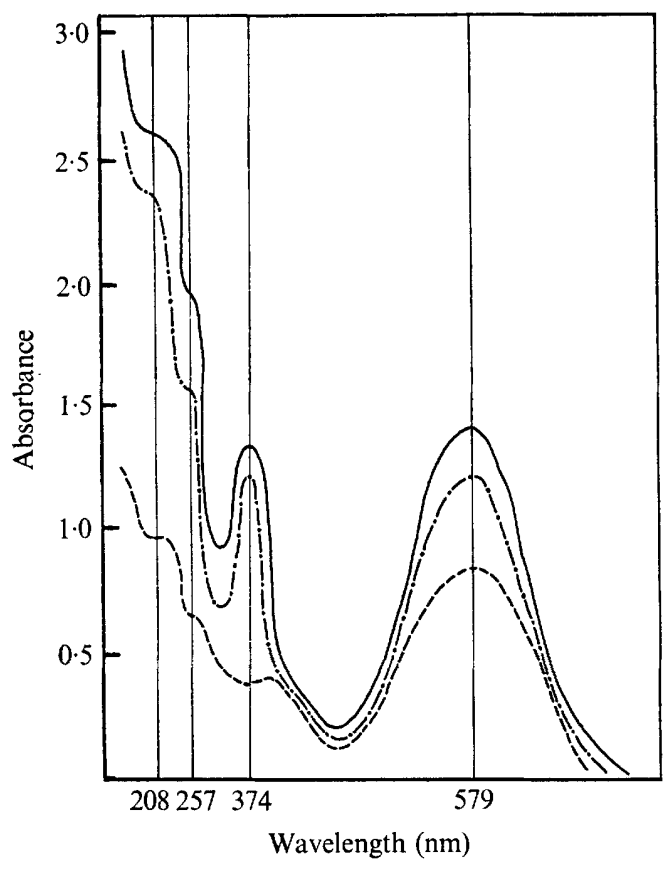

Fig. 3

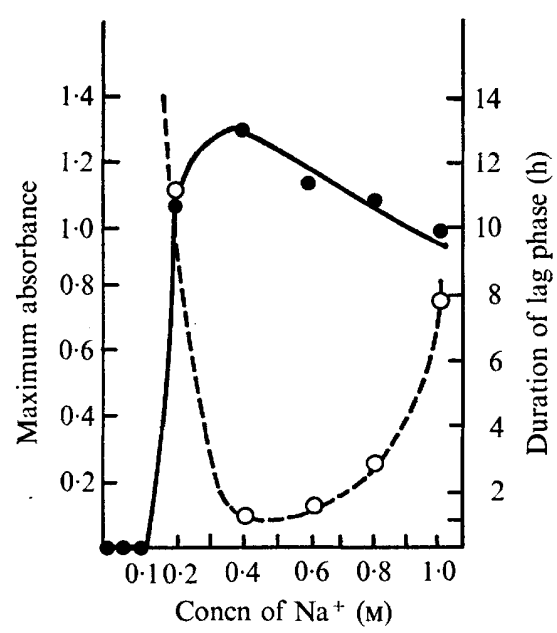

Fig. 4

Fig. 3. Absorption spectrum of the pigment produced by NCMBI94I (----) and NCMBI942 $(-\cdot-\cdot \cdot-\cdot)$ in ethanol, and of pure violacein $(-)$ (taken from Sneath, 1956a).

Fig. 4. Sodium requirements of the strain NCMBI94I studied by means of a recording biophotometer (with incubation in stirred medium at $25^{\circ} \mathrm{C}$ ). The other five strains gave similar results, except NCMBI 890 which was less inhibited by $\mathrm{Na}^{+}$concentrations higher than $0.6 \mathrm{M}$. bance of cultures; $O$, duration of lag phase.

produced by strains NCMBI94I and NCMBI942 appeared identical with violacein (Fig. 3), usually synthesized by Chromobacterium spp.; it gave colour reactions specific to this pigment: emerald green in sulphuric acid, bright blue in acetic acid, and green turning yellow in $10 \% \mathrm{KOH}$.

None of the bacteria grew in media containing less than $0.2 \mathrm{M}-\mathrm{Na}^{+}$, the optimum for growth being 0.4 to $0.6 \mathrm{M}-\mathrm{Na}^{+}$, i.e. approximately the same as in seawater. They were inhibited in higher concentrations (Fig. 4). Sodium also seems essential for maintaining the integrity of their walls, since they lysed in a few seconds in a sodium-free solution even in the presence of high concentrations of other ions $\left(\mathrm{K}^{+}, \mathrm{Ca}^{2+}, \mathrm{Mg}^{2+}\right)$ (Table $\left.\mathrm{I}\right)$. The absence of divalent cations did not cause any cellular deterioration. Moreover, a saline solution with only $\mathrm{Na}^{+}$and $\mathrm{K}^{+}$salts could prevent much of the lysis, whereas $\mathrm{Mg}^{2+}$ or $\mathrm{Ca}^{2+}$ salts were ineffective. Sucrose did not prevent lysis.

These results agree with those of other workers who have suggested that the need for $\mathrm{Na}^{+}$in metabolism and in the maintenance of the wall is one of the main characteristics of the 'true' marine bacteria (Scholes \& Shewan, 1964; McLeod, 1965; DeVoe \& Oginsky, 1969a, $b$ ).

The GC ratios of the DNA of all the bacteria were relatively low: $46 \cdot 9,4 \mathrm{I} \cdot 5,47 \cdot \mathrm{I}, 42 \cdot 2$ and $42.0 \%$ for NCMBI943, NCMBI 889 , NCMBI 890 , NCMBI942 and NCMBI94I, respectively. 


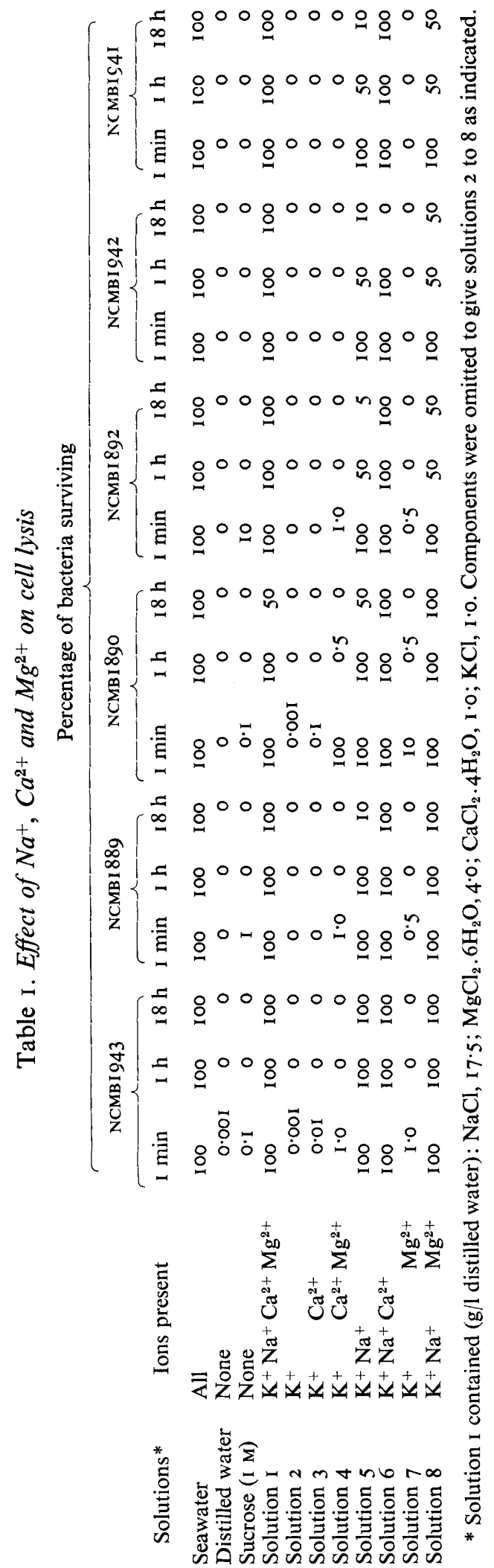




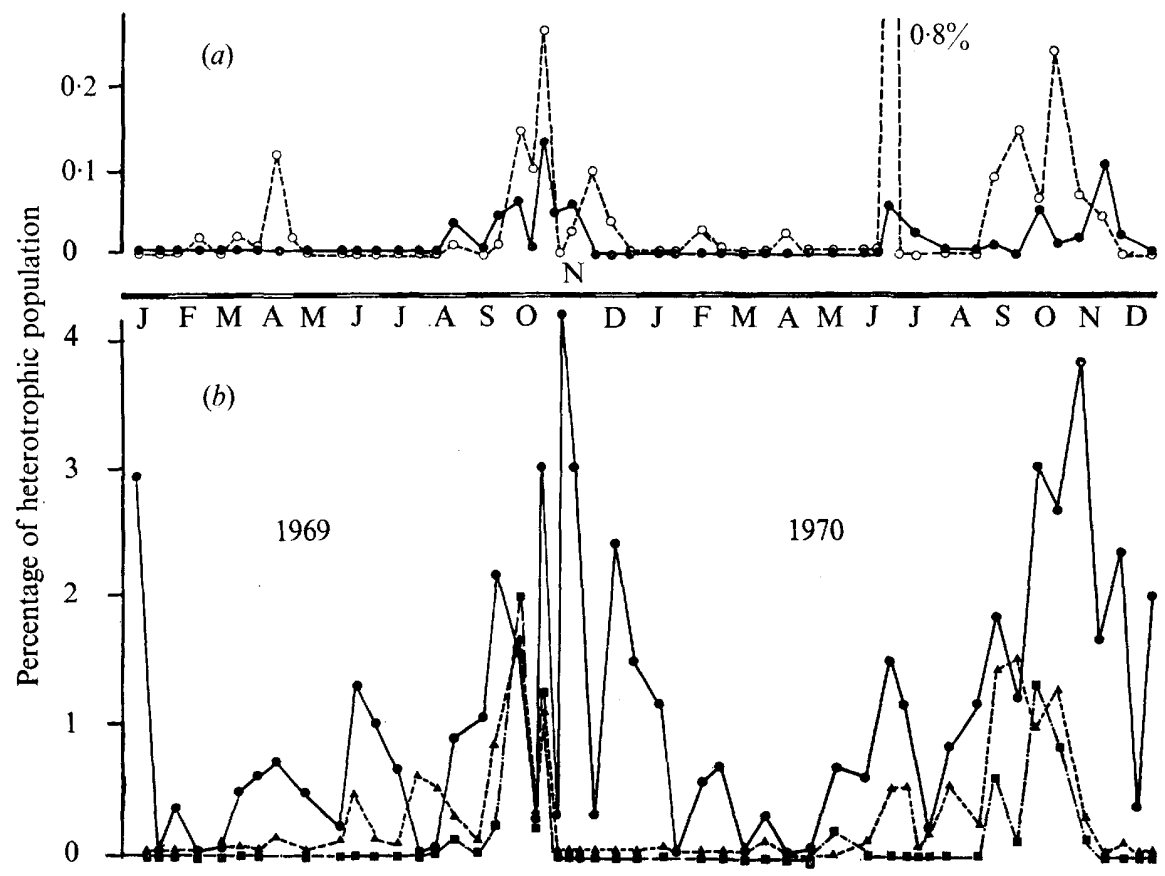

Fig. 5. Seasonal variations in the counts of the six bacterial types, over two successive annual cycles (I969-70). (a) O, NCMBI892; O, NCMBI943. (b) O, NCMBI889;

\section{Quantitative variations during the year.}

In the marine biotope studied, the six bacterial types mainly appeared during the second half of the year, with maximum densities in September and October for strains similar to NCMBI 943, NCMBI 890, NCMBI 892, NCMBI 94 I and NCMBI942, and from November to January for strain NCMBI 889 (Fig. 5).

\section{DISCUSSION}

The six bacteria isolated can be placed in Pseudomonas group IV of Shewan et al. (1960). However, their low \% GC relative to recognized Pseudomonas species (60 to $70 \% \mathrm{GC}$ ), the absence of catalase and their sodium requirements remove them from this genus. They are similar to the marine pseudomonas studied by Lee (I973), which show a strong similarity to Alteromonas (Baumann, Baumann, Mandel \& Allen, 1972).

Assuming that they are 'marine pseudomonads', these bacteria are distinguished by their strong antibacterial properties. Gauthier (1970), using NCMBI890 and some violet types, showed that the characteristics of the antibiosis appear to be closely related to the structure of the bacteria. The substances responsible for the activity are polysaccharides, probably bound to the outside layers of the wall, and could constitute the pseudocapsule seen in electron micrographs. These antibacterial substances inhibit the bacteria producing them, during their lag and stationary phases, so giving them a short life in the usual culture media. They must be subcultured every 4 to 5 days, whatever the medium. The antagonistic activity is partly or totally neutralized by catalase either added to the medium or present in the bacteria used for antibiosis tests (Gauthier, 1972). This is similar to the 'catalase effect' described by Sneath (I956a) for species of Chromobacterium, for which no mechanism of antibiosis has been described. The absence of catalase and their property of self inhibition 
probably involves major modifications in the respiratory metabolism of the bacteria studied here. They may differ in their structure and functions from the true pseudomonads, and may thus be a physiologically isolated group.

Two strains, NCMBI94I and NCMB 1942, produced violacein, which was studied by Leifson (1956) and Sneath (1956a) in the genus Chromobacterium, and by Hamilton \& Austin (1967) in Chromobacterium marinum. Chromobacterium marinum also has a very short life on solid media and its reported properties are similar to those of NCMBI94I and NCMBI942. It was included in the genus Chromobacterium because it produced violacein, showed a 'catalase effect' and had a mixed flagellation (Sneath, I956 b), properties regarded as specific to the genus. Both NGMBI94I and NCMBI942 contain violacein and show the 'catalase effect'. However, their flagellation is always monotrichous and polar. The presence of the same pigment in two different bacteria does not necessarily imply a close phylogenetic relationship between them. Starr (1958) showed that the blue pigments of Corynebacterium insidiosum and Pseudomonas indigofera are identical. In addition, the \% GC of the genus Chromobacterium (65 to $72 \%$; De Ley \& Van Muylen, I963) is much higher than that of NCMBI 941 and NCMBI942, and such a difference is sufficient to exclude them from the genus. Thus the 'catalase effect' can no longer be regarded as specific to the genus Chromobacterium.

The growing interest in marine microbiology is due in part to the existence of species with properties which enable them to survive and grow under the often unfavourable conditions in the marine environment. Some physiological properties have been used to try to define the marine nature of strains isolated from the sea, but the problem of whether there exist specifically marine bacteria remains unresolved. In our opinion the best definition of marine bacteria is that they are the only bacteria able to multiply in the sea and play an active part in the life-cycle of oceans. Such a definition fits the bacteria described here. They require seawater for growth and survival, appear regularly in each annual cycle during the autumn phytoplanktonic blooms rich in diatoms, and are present for a good part of the winter. At times they form more than $5 \%$ of the bacterial heterotrophs which can be cultured in the laboratory. They disappear when the phytoplanktonic population becomes composed of Dinoflagellates. The role of these bacteria in the sea is not known but their special inhibitory properties may play some part in determining the relationships within the microbial ecology of the sea.

\section{REFERENCES}

BaAm, B. R., Gandhi, N. M. \& Freitas, Y. M. (I966). Antibiotic activity of marine micro-organisms. Helgoländer wissenschaftliche Meeresuntersuchungen $13,18 \mathrm{I}-185$.

Baumann, L., Baumann, P., Mandel, M. \& Allen, R. A. (1972). Taxonomy of aerobic marine Eubacteria. Journal of Bacteriology 110, 402-429.

Bonde, G. C. (1968). Studies on the dispersion and disappearance phenomena of enteric bacteria in the marine environment. Revue internationale d'océanographie médicale ro, 17-44.

Buck, J. D., Ahearn, D. G., Roth, F. J. \& Meyers, S. P. (1963). Inhibition of yeasts by a marine bacterium. Journal of Bacteriology 85, I I 32-I 135.

Buck, J. D. \& MEYers, S. P. (I965). Antiyeast activity in marine environment. I. Ecological considerations. Limnology and Oceanography 10, 385-391.

Buck, J. D. \& MeYers, S. P. (I966). "In vitro" inhibition of Rhodotorula minuta by a variant of the marine bacterium Pseudomonas piscicida. Helgoländer wissenschaftliche Meeresuntersuchungen 13, 171-180.

Buck, J. D., MeYers, S. P. \& Kamp, K. M. (1962). Marine bacteria with antiyeast activity. Science, New York 138, 1339-1340.

Burkholder, P. R., Pfister, R. M. \& Leitz, F. H. (I966). Production of pyrrole antibiotic by a marine bacterium. Applied Microbiology 14, 649-653.

Chabbert, Y. A. (1963). L'antibiogramme. St. Mandé: M. R. Dujarric de la Tourelle.

De Ley, J. \& VAN MuYlen, J. (I963). Some applications of desoxyribonucleic acid base composition in bacterial taxonomy. Antonie van Leeuwenhoek 29, 344-358. 
DEVOE, I. W. \& OGINSKY, E. L. (I969a). Antagonistic effect of monovalent cations in maintenance of cellular integrity of a marine bacterium. Journal of Bacteriology 98, 1355-1367.

Devoe, I. W. \& OgInsKy, E. L. (1969b). Cation interactions and biochemical composition of cell envelope of a marine bacterium. Journal of Bacteriology 98, 1 368-1 377.

DoggetT, R. G. (1968). New anti Pseudomonas agent isolated from a marine Vibrio. Journal of Bacteriology 95, $1972-1973$.

GaUTHIER, M. J. (1969). Substances antibactériennes produites par les bactéries marines. I. Etude systématique de l'activité antagoniste de souches marines vis-à-vis de genres telluriques aérobies. Revue internationale d'océanographie médicale 15-16, 4I-59.

GAUTHIER, M. J. (1970). Substances antibiotiques produites par les bactéries marines. II. Lipopolysaccharide antibiotiques produites par certains germes marins appartenant aux genres Pseudomonas et Chromobacterium. Revue internationale d'océanographie médicale 17, 23-45.

GAUTHIER, M. J. (1972). Antagonismes et synergies dans l'antibiose chez certaines bactéries marines. Rôle de certains enzymes respiratoires dans ces phénomènes. Revue internationale d'océanographie médicale 26, 65-84.

Gratia, A. \& FredericQ, P. (I946). Diversité des souches antibiotiques de E. coli et étendue variable de leur champ d'action. Comptes rendus de séances de la Société de biologie 140, 1032-1033.

GreIN, A. \& MeYerS, S. P. (1958). Growth characteristics and antibiotic production of Actinomycetes isolated from littoral sediments and materials suspended in sea-water. Journal of Bacteriology 76, 457463.

Hamilton, R. D. \& Austin, K. E. (1967). Physiological and cultural characteristics of Chromobacterium marinum sp. n. Antonie van Leeuwenhoek 33, 257-264.

Hendrie, M. S., Hodgkiss, W. \& SheWAN, J. M. (1964). Considerations on organisms of the AchromobacterAlcaligenes group. Annales de l'Institut Pasteur de Lille 15, 43-59.

King, E. O., WARD, M. K. \& RANEy, D. E. (1954). Two simple media for the demonstration of pyocyanin and fluorecin. Journal of Laboratory and Clinical Medicine 44, 30I-307.

LebedeVA, M. N. \& MARKIANovic, E. M. (197I). Antibiotic features of heterotrophic bacteria in southern seas. Proceedings of the 5th International Colloquium of Medical Oceanography, Messine, 335-352.

LEE, J. V. (1973). Some comparative biochemical and physiological studies on selected Gram-negative bacteria. $\mathrm{Ph} . \mathrm{D}$. thesis, University of Aberdeen.

LEIFson, E. (1956). Morphological and physiological characteristics of the genus Chromobắcterium. Journal of Bacteriology 7r, 393-400.

Liefson, E. (1963). Determination of carbohydrate metabolism of marine bacteria. Journal of Bacteriology 85, II $83-1184$.

MCLEOD, R. A. (1965). The question of the existence of specific marine bacteria. Bacteriological Reviews 29, 9-23.

MARmur, J. (196I). A procedure for the isolation of desoxyribonucleic acid from microorganisms. Journal of Molecular Biology 3, 208-21 8 .

MARMUR, J. \& DotY, P. (1962). Determination of the base composition of desoxyribonucleic acid from its thermal denaturation temperature. Journal of Molecular Biology 5, I09-I 18.

MERKEL, J. R. (1972). Influence of salts on the vibriostatic action of 2,4-diamino-6,7-diisopropyl pteridine. Archiv für Mikrobiologie 81, 379-382.

Rhodes, M. E. (1958). The cytology of Pseudomonas spp. as revealed by a silver-plating staining method. Journal of General Microbiology 18, 639-648.

RosenFeld, D. W. \& ZoBell, C. E. (1947). Antibiotic production by marine microorganisms. Journal of Bacteriology 54, 393-398.

Scholes, R. B. \& Shewan, J. M. (1964). The present status of some aspects of marine microbiology. Advances in Marine Biology, U.S.A. 2, 133-170.

Shewan, J. M., Hobrs, G. \& Hodgkiss, W. (1960). A determinative scheme for the identification of certain genera of Gram-negative bacteria, with special reference to the Pseudomonadaceae. Journal of Applied Bacteriology 23, 379-390.

SNEATH, P. H. A. (1956a). Cultural and biochemical characteristics of the genus Chromobacterium. Journal of General Microbiology 15, 70-98.

SNEATH, P. H. A. $(1956 b)$. The change from polar to peritrichous flagellations in Chromobacterium sp. Journal of General Microbiology 15, 99-I05.

Starr, M. P. (1958). The blue pigment of Corynebacterium insidiosum. Archiv für Mikrobiologie 30, 325-334. Strong, F. M. (1944). Isolation of violacein. Science, New York 10o, 287. 